\title{
Soil Water Depletion by Yucca
}

\section{R.E. SOSEBEE, F.M. CHURCHILL, AND C.W. GREEN}

\section{Abstract}

Encroachment of Yucca sp. onto newly cleared rangelands often presents a larger problem than caused by the noxious species initially controlled. Densities of yucca often approach or exceed 5000 plants/ha, potentially depleting soil water and reducing forage production. An evaluation of soil water $(0$ to $60 \mathrm{~cm}$ depths) during April 1971 through August 1975 revealed the yucca-infested rangeland had a significantly lower water content than yucca-free rangeland. Herbage production was also significantly reduced by yucca during years with a higher soil water content. Partially thinning yucca densities did not increase soil water content. Soil water storage was increased only when all yucca was removed.

Restoration and conservation of native rangelands in the Southwest are among the most important problems confronting the ranching industry today. Control of noxious brush and some weeds ranks as a high priority a mong ranchers in the Southwest.

Approximately 310 million ha of rangeland in the southwestern U.S. (Texas, New Mexico, and Arizona) are infested with noxious brush (U.S. Dep. Agr. Soil Conserv. Serv. 1978) including plants such as mesquite (Prosopis sp.), "cedar" (Juniper sp.), and oak (Quercus sp.). Active programs have been underway for many years to control noxious brush. Following removal of some major noxious species, often secondary species that are equally as noxious invade the area. Following control of honey mesquite $(P$. glandulosa), ash and redberry juniper ( $J$. ashii and $J$. pinchotii, respectively), yucca (Yucca sp.) often invade the cleared areas. It has been estimated that approximately 4.9 million ha in Texas alone (predominately in the Panhandle area) are infested with $Y$. glauca (Robison 1968).

Chemical control of $Y$. glauca in the Panhandle of Texas increased desirable herbage production approximately $37 \%$ over untreated areas (Robison 1968). Much of the increase occurred within the dead yucca clumps. Significant production of forage species follows control of Utah juniper (Juniperus osteospermus) (Clary 1971) and mixed brush in South Texas (Dodd and Holtz 1975, Gonzales and Dodd 1979, Durham et al. 1975, and Scifres and Polk 1975). Control of velvet mesquite ( $P$. velutina) increased perennial grass production $52 \%$ over a period of 10 years in southern Arizona (Cable and Martin 1975). Similarly, control of honey mesquite increased herbage production over a 5-year period in the Rolling Plains of Texas (Dahl et al. 1978).

Presumably, increases in forge production result from increased soil water following control of undesirable species. Herbage yields are highly correlated to soil water content, particularly to preseason stored water (Dahl 1963; Gonzales and Dodd 1979).

This study was initiated to evaluate the influence of yucca ( $Y$. glauca, $Y$. constricta, and their hybrids) on soil water depletion and herbage response to different densities of yucca.

\section{Study Area and Experimental Procedures}

This study was conducted from April 1971 through August 1975

Authors are professor. Department of Range Wildlife Management, Texas Tech University, Lubbock, and professor and graduate research assistant, Department of Agriculture, Abilene Christian University, Abilene, Texas. Green's present address is USDA-SCS, San Angelo, Texas.

The authors wish to thank Mr. Garnett Wilkes for the priviledge of studying on his ranch. We also thank the many students who participated in this project and assisted in collecting and compiling the data. Contribution No. T-9-246 of the College of Agricultural Sciences, Texas Tech University.

Manuscript received November 14,1980 on an Edward's Plateau outcropping within the Rolling Plains of Texas, near Sweetwater. Physiographically, the area is located on the Callahan Divide, in Nolan County, which forms a boundary between the Colorado and Brazos River basins. The soils of the area are characterized by a Berda fine sandy loam on a Mixland range site.

Climate of the area is intermediate between the subhumid climate of east Texas and the semiarid climate of the Southwest. The average annual precipitation is $61 \mathrm{~cm}$, most of which occurs in the form of rain. Most $(76 \%)$ of the rainfall occurs April through October as localized, short duration thunderstorms of high intensities.

Herbaceous vegetation of the study area consisted primarily of sideoats grama (Bouteloua curtipendula), hairy grama (B. hirsuta), blue grama (B. gracilis), silver bluestem (Bothriochloa sacchroides), perennial threeawns (Aristida purpurea, $A$. wrightii, $A$. longiseta, $A$, glauca, and A. oligantha), sand dropseed (Sporobolus cryptandrus), buffalograss (Buchloe dactyloides), hooded windmill (Chloris cuculata), Reverchon's panic (Setaria reverchonii), and Texas croton (Croton texensis). Following control of ash and redberry juniper, yucca invaded the area and became the dominant noxious species. The density of yucca on the study area was approximately 5000 plants/ha (determined by counting the number of individual plants $/ 0.1 \mathrm{ha}$ ).

The study was designed as randomized complete blocks with 3 treatments and 3 blocks. All blocks were $30 \times 30 \mathrm{~m}$ and separated by $4.6 \mathrm{~m}$ buffers. The treatments consisted of no yucca, approximately 2500 yucca plants/ha and approximately 5000 yucca plants/ha.

Originally, yucca was hand-grubbed from the treatments containing no yucca and 2500 plants/ha. Yucca densities were maintained for the duration of the study by hand-grubbing periodically. All woody plants were similarly removed from every plot by handgrubbing.

Soil water content was measured weekly June through August and monthly from September through May each year. Soil cores were collected in $15-\mathrm{cm}$ increments to a depth of $60-\mathrm{cm}$ from which soil water content was determined gravimetrically. Soil samples were oven-dried at $100^{\circ} \mathrm{C}$ for a minimum of $24 \mathrm{hr}$. The soil water content $(\%)$ represented an average from 4 random soil cores/ treatment/block/sampling date. Precipitation was recorded on the study area.

Herbage yields were measured during August of 1972, 1973, and 1974. Herbaceous plants were harvested by species and yields represented an average obtained from 5 random $0.45 \mathrm{~m}^{2}$ quadrats/treatment/block

\section{Results and Discussion}

Evidence of the effect of yucca on soil water depletion was observed from April 1971 through August 1975. Soil water content was significantly higher where yucca had been removed compared to the treatments that consisted of either 2500 or 5000 plants/ha (Fig. 1). The soil water content wa significantly higher $(P=0.05)$ in the areas consisting of no yucca vs. a reas consisting of either 2500 or 5000 plants / ha. The average soil water content of the treatment in which yucca had been removed ranged from $5.4 \%$ in July to $15.4 \%$ in October. However, the average soil water content ranged from a low of $4.8 \%$ and $4.7 \%$ in July to a high of $14.3 \%$ and $14.0 \%$ in October in treatments consisting of 2500 and 5000 plants/ha, respectively. Seemingly yucca must be completely controlled or removed to significantly increase soil water storage. Partial elimination or thinning yucca is of little or no significance in soil water conservation. Similar results have been found in mesquite (B.E. Dahl, unpublished data; Thomas 1976) and broom snakeweed (Ueckert 1979). 

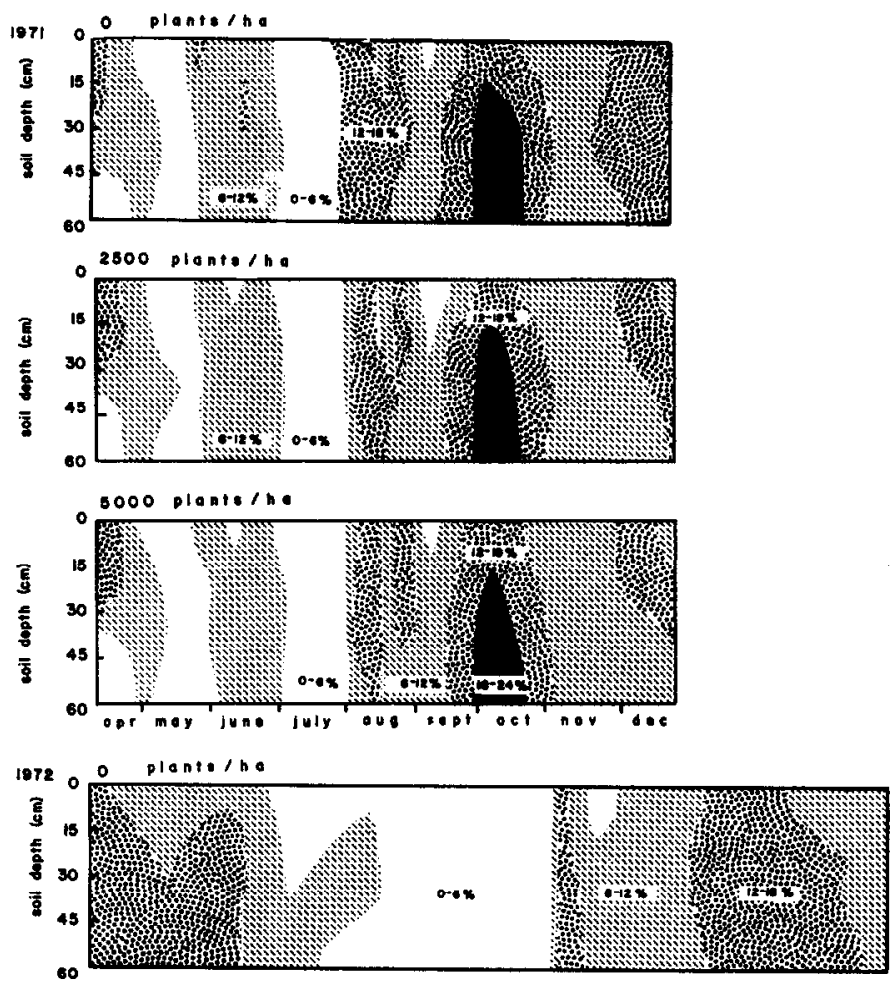

$$
02500 \text { plant o iho }
$$
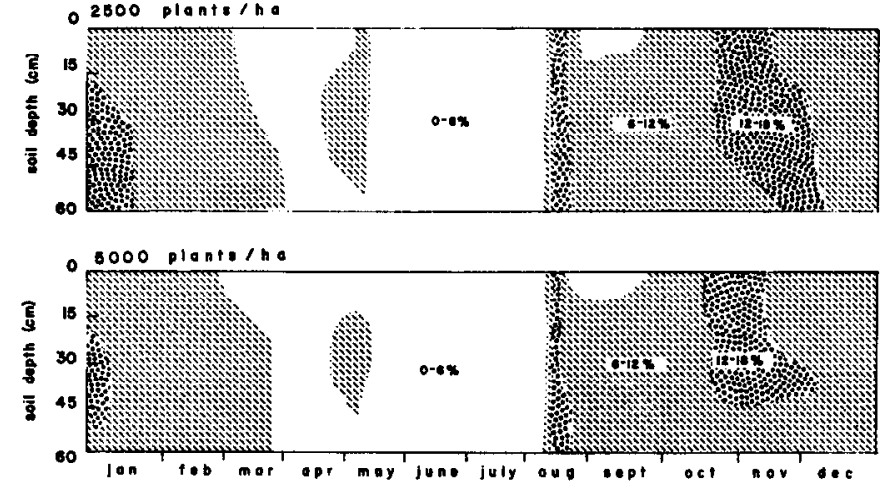

Fig. 1. Soil water content (\%) to a depth of $60 \mathrm{~cm}$ (average depth to caliche) as influenced by different densities of yucca from April, 1971 through August, 1975.

Soil water content exhibited seasonal trends since most of the precipitation was received during August and September (Fig. 2). Soil water content remained relatively high throughout most of the fall and winter. During the spring, soil water content was consistently lower, which should be expected because of the amount of plant growth during this period of the year. As the rate of plant growth slowed and the plants entered quiescence during the latter part of the summer, soil water content increased in relation to the amount of precipitation.

The growth habits of yucca also affected the amount of water retained in the soil. Root excavations revealed that yucca commonly develops underground stems $7.5 \mathrm{~cm}$ in diameter at depths of 45 to $60 \mathrm{~cm}$, at which depth the stems branch and grow laterally either parallel with or ascending to the soil's surface. Buds form on the underground stems and ultimately emerge as new plants. The underground stems have many roots varying from 2 to $4 \mathrm{~mm}$ in diameter and may extend laterally for several meters. Thus, yucca has the capacity to deplete significant amounts of soil water. The pattern of soil water depletion indicates that the depth of most active root absorption occurs between 45 and $60 \mathrm{~cm}$ (especially on shallow soils).

Herbage production was related to yucca control and soil water depletion. Complete removal of yucca significantly increased grass
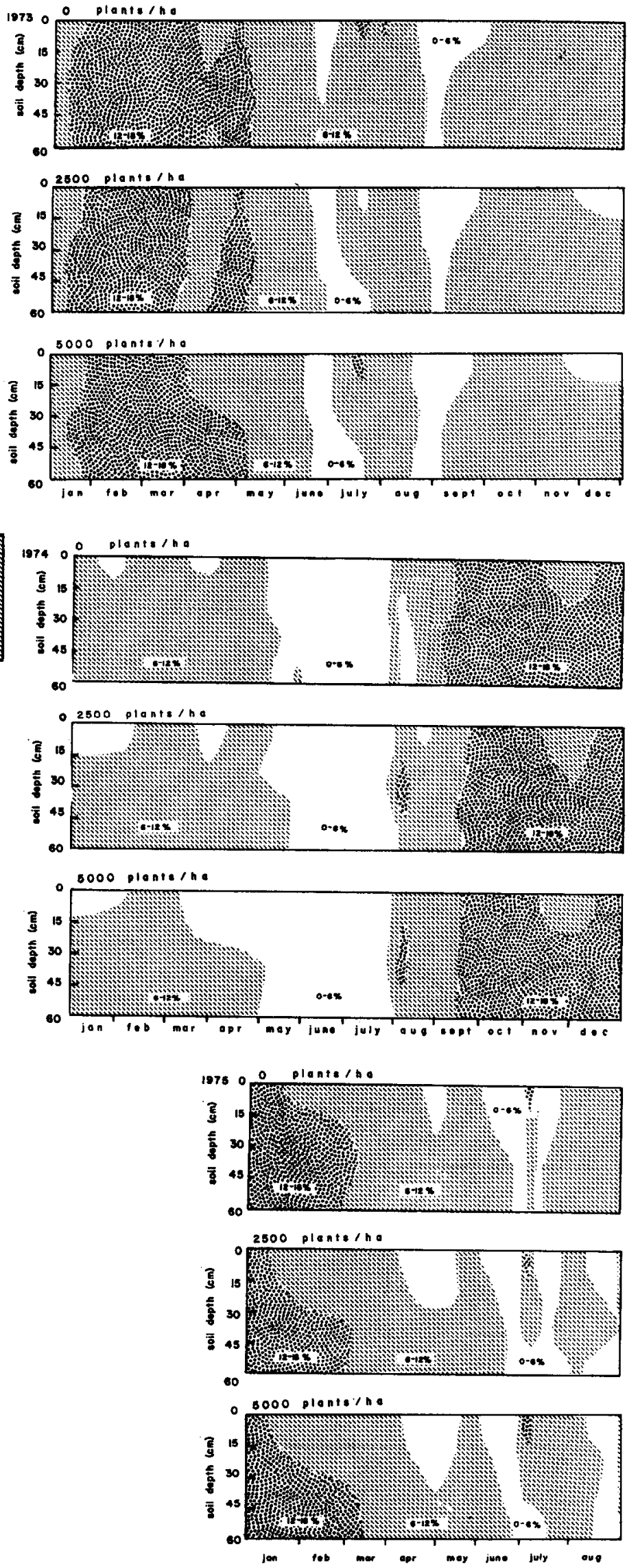

yield during 1973 (Table 1) while forb production was concomitantly reduced. The significant increase in grass production during 1973 seemed to be related to the amount of precipitation received during the fall of 1972 (Fig. 2). Although production of warm- 
Table 1. Grass and forb production (kg/ha) in 1972, 1973, and 1974 as infuenced by 3 densities of yucca $(0,2500,5000$ plants/ha $)$ growing on shallow soils near Sweetwater, Texas.

\begin{tabular}{|c|c|c|c|c|c|}
\hline \multirow{2}{*}{$\begin{array}{l}\text { No. yucca } \\
\text { plants/ha }\end{array}$} & \multicolumn{3}{|c|}{ Year } & \multirow[b]{2}{*}{ - - } & \multirow[b]{2}{*}{$\bar{x}^{2}$} \\
\hline & 1972 & 1973 & 1974 & & \\
\hline \multicolumn{6}{|c|}{ Grass production } \\
\hline 0 & $\begin{array}{c}A^{\prime} \\
904 \mathrm{a}\end{array}$ & $\begin{array}{c}B \\
1937 \mathrm{~b}\end{array}$ & $\begin{array}{c}A \\
687 \mathrm{a}\end{array}$ & & 1176 \\
\hline 2500 & $\begin{array}{c}\mathrm{A} \\
880 \mathrm{a}\end{array}$ & $\begin{array}{c}A \\
1512 \mathrm{a}\end{array}$ & $\underset{803 \mathrm{a}}{\mathrm{A}}$ & & 1065 \\
\hline 5000 & $\underset{927 \mathrm{a}}{\mathrm{A}}$ & $\underset{1584 \mathrm{a}}{\mathrm{A}}$ & $\begin{array}{c}A \\
850 \mathrm{a}\end{array}$ & & 1120 \\
\hline \multicolumn{6}{|c|}{ Forb production } \\
\hline 0 & $\stackrel{A}{450 \mathrm{x}}$ & $\begin{array}{c}\text { B } \\
215 x\end{array}$ & $\begin{array}{c}\text { B } \\
229 \mathrm{x}\end{array}$ & & 298 \\
\hline 2500 & $\begin{array}{c}A \\
365 x\end{array}$ & $\begin{array}{c}A \\
284 x\end{array}$ & $\stackrel{a}{150 x}$ & & 266 \\
\hline 5000 & $\begin{array}{c}A \\
429 x\end{array}$ & $\frac{A}{268 x}$ & $\begin{array}{c}\text { A } \\
104 \mathrm{x}\end{array}$ & & 267 \\
\hline
\end{tabular}

IValues in a row with similar capital letter superscripts are not significantly different $(P=0.05)$. Values in a column followed by similar lower case letters are not significantly different $(P=0.05)$. No statistical comparisons were made between grass and forb production.

'Not included in a statistical analyses.

season perennials such as silver bluestems, three-awns, and sand dropseed was increased, Texas wintergrass (Stipa leucotricha) accounted for a substantial amount of the production in 1973. Similar results that indicate herbage yield of native plants is more closely related to the amount of precipitation received during the fall preceding the growth season in which growth is expressed than to the amount received during the growing season have been reported by Dahl (1963). Interestingly, even during a "wet year" there apparently is not sufficient soil water to support dense stand s of yucca ( 5000 plants/ha) and an increase in grass production. During "wet years" grass production is reduced apparently because of competition from yucca.

\section{Summary and Conclusions}

Many acres of mesquite and juniper infested rangeland are controlled annually, only to be invaded by other noxious species such as yucca. Stands of yucca often become very dense (5000 plants/ha) and compete with more desirable species for water, nutrients, and even space.

Complete removal or control of yucca significantly increases amounts of soil water storage in the rooting zone of more desirable herbaceous plants. Partial control or thinning has little effect on increasing soil water content. Similarly, complete control of yucca allows herbage yield to increase when adequate precipitation occurs; whereas, no substantial yields occur if yucca is present in moderate to dense stands, even if precipitation is adequate. Therefore, if one decides to control yucca to increase soil water content and concomitant herbage yield, one must strive for complete control.

\section{Literature Cited}

Anonymous. 1978. Fifteen state random sample survey of acreage infested with brush. (Mimeogr. material).

Cable, D.R., and S.C. Martin. 1976. Vegetation responses to grazing, rainfall, site condition, and mesquite control on semi-desert range. USDA-FS Rs. Pap. RM-149. Rocky Mountain Forest and Range Exp. Sta., Fort. Collins, Colo. 24 p.

Clary, W.P. 1971. Effects of Utah juniper removal on herbage yields from Springville soils. J. Range Manage. 24:373-378.

Dahl, B.E., R.E. Sosebee, J.P. Goen, and C.S. Brumley. 1978. Will mesquite control with 2,4,5-T enhance grass production? J. Range Manage. $31: 129-131$.

Dodd, J.D., and S.T. Holtz. 1975. Integration of burning with mechanical manipulation of South Texas grassland, p. 17-18. In: Rangeland Resource Research 1971-1974. Texas Agr. Exp. Sta. Consolidated Progress Rep. 334l. Texas A\&M Univ., College Station.

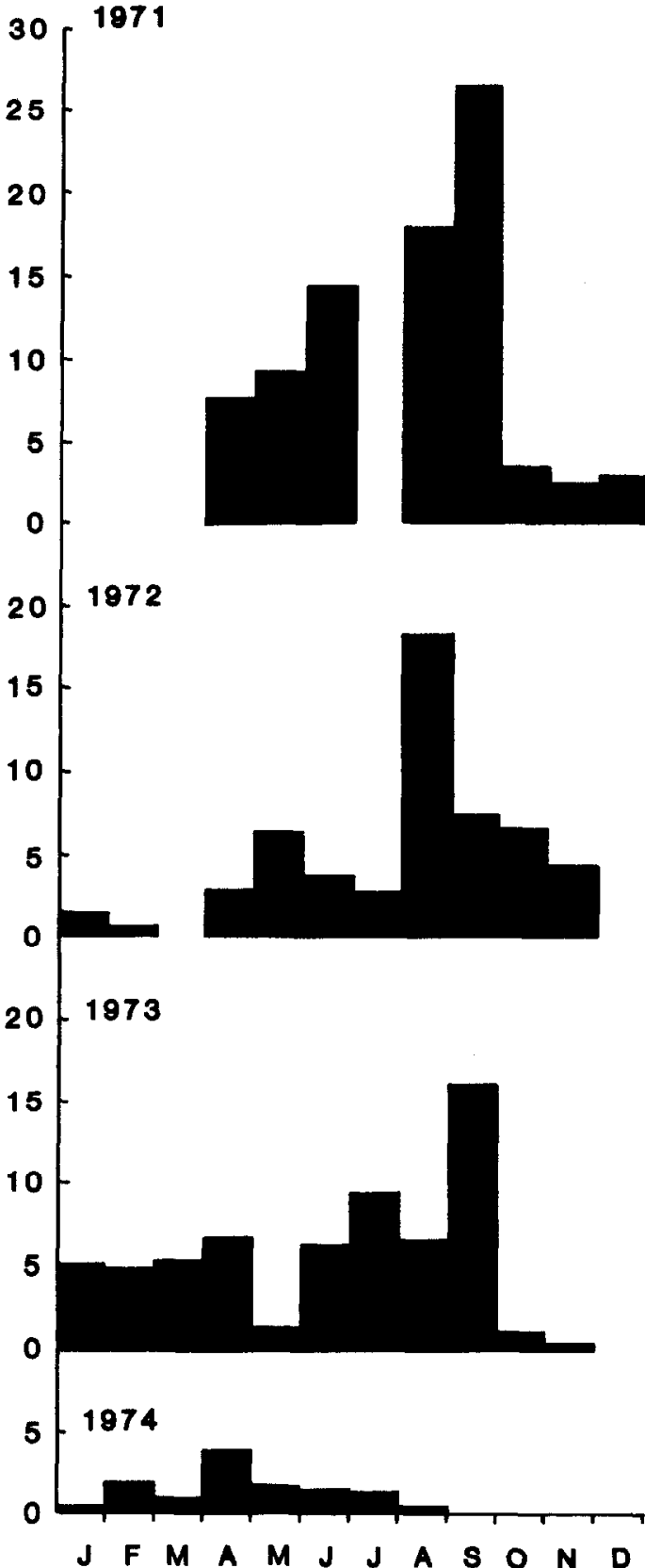

Fig. 2. Monthly precipitation (April, 1971 through August, 1975) that influenced the soil water content and herbage yield on a Mixland range site near Sweetwater Texas.

Durham, G.P., C.J. Scifres, J.L. Mutz, and M. Brownfield. 1975. Range forage production and utilization following aerial application of herbicides to South Texas rangeland, p. 21-22. In: Rangeland Resources Research 1971-1974. Texas Agr. Exp. Sta. Consolidated Progress Rep. 3341. Texas A\&M Univ., College Station.

Gonzales, C.L., and J.D. Dodd. 1979. Production response of native and introduced grasses to mechanical brush manipulation, seeding and fertilization. J. Range Manage. 32:305-309.

Robison, E.D. 1968. Chemical control of yucca in the Texas Panhandle, p. 18-21. PR-2588. In: Brush Research in Texas. Texas Agr. Exp. Consolidated Progress Rep. 2583-2609. Texas A\&M Univ., College Station.

Scifres, C.J., and D.B. Polk, Jr. 1975. Influence of aerial herbicide application on native forage production in the Rolling Plains, p. 23-24. In: Rangeland Resources Research 1971-1974. Texas Agr. Exp. Sta. Consolidated Progress Rep. 3341. Texas A\&M Univ., College Station.

Thomas, G.W. 1976. Mesquite leaf diffusive resistence under various environmental conditions. M.S. Thesis. Texas Tech Univ., Lubbock. 53 p.

Ueckert, D.N. 1979. Broom snakeweed: effect on shortgrass forage production and soil water depletion. J. Range Manage. 32:216-220. 